\title{
SISTEM INFORMASI GEOGRAFIS WILAYAH RAWAN BANJIR DI KOTA PEKANBARU
}

\author{
${ }^{1)}$ Luluk Elvitaria, ${ }^{2)}$ Miftahul Khasani \\ ${ }^{1) 2)}$ Teknik Inforamtika, Teknik, Universitas Abdurrab \\ Jl. Riau Ujung, Pekanbaru, 28282 \\ E-Mail :luluk@univrab.ac.id,miftahulkhasani001@gmail.com
}

\begin{abstract}
ABSTRAK
Berdasarkan letak geografis wilayah Kota Pekanbaru merupakan salah satu daerah yang termasuk ke dalam daerah rawan banjir bahkan dikatakan Kota Pekanbaru termasuk kedalam zona merah terkait banjir melihat dari mayoritas daerah yang ada adalah daerah rawah dan pinggiran sungai. Badan Nasional Penanggulangan Banjir (BNPB) mencatat, Kota Pekanbaru adalah salah satu Kota yang rawan banjir di Pulau Sumatra. Selain mementukan daerah rawan banjir bagi Dinas BPBD daerah Kota Pekanbaru, masyarakat juga ingin mengetahui lokasi yang sering banjir dan menentukan kapasitas lama intensitas hujan yang akan mengakibatkan banjir, sehingga tidak menghambat perjalanan beraktifitas sehari-hari. Untuk menangani masalah ini, perlu dibangun sebuah Sistem Informasi Geografis yang dapat menentukan daerah yang sering terjadi banjir alam. Sistem informasi geografis diharapkan dapat membantu Dinas BPBD dalam mengelola data banjir yang pernah terjadi berada di Kota Pekanbaru, serta membantu memberikan informasi tentang banjir yang dibutuhkan oleh masyarakat untuk mengantisipasi kejadian banjir selanjutnya.
\end{abstract}

Kata Kunci: Banjir, BNPB, kota pekanbaru, wilayah, sistem informasi geografis

\begin{abstract}
Based on the geographical location of Pekanbaru City is one of the areas included in flood-prone areas, even said that the city of Pekanbaru is included in the red zone related to flooding, seeing from the majority of the existing area is the rawah and river banks. The National Flood Mitigation Agency (BNPB) noted that the city of Pekanbaru is one of the flood-prone cities on the island of Sumatra. In addition to determining flood-prone areas for the Regional BPBD Office in Pekanbaru City, the community also wants to know the location that often floods and determine the long-term rain intensity capacity that will cause flooding, so that it does not hinder the daily activities. To deal with this problem, a Geographical Information System needs to be developed that can determine areas that often occur in natural flooding. Geographical information systems are expected to be able to assist the BPBD Office in managing flood data that has occurred in the city of Pekanbaru, and help provide information about floods that are needed by the community to anticipate further flood events.
\end{abstract}

Keywords: flood, BNPB, Pekanbaru City, region, geographic information system

\section{PENDAHULUAN}

Wilayah Kota Pekanbaru sangat strategis, terletak di tengah-tengah Pulau Sumatera yang dapat dilalui dengan perhubungan darat ke seluruh kawasan. Secara geografis Kota Pekanbaru terletak antara 1010 14'- 1010 34' Bujur Timur dan 00 25'- 0045 Lintang Utara. Dari hasil pengukuran atau pematokan di lapangan oleh BPN Tingkat I Riau, ditetapkan luas wilayah Kota Pekanbaru 632,26 km2. Batas-batas Kota Pekanbaru adalah sebagai berikut (http://www.pekanbaru.go.id, 2017) : (1) Sebelah utara berbatasan dengan Kabupaten

Kampar dan Siak. (2) Sebelah timur berbatasan dengan Kabupaten Pelalawan. (3) Sebelah selatan berbatasan dengan Kabupaten Kampar dan Pelalawan. (4) Sebelah barat berbatasan dengan Kabupaten Kampar. Berdasarkan letak geografisnya tersebut wilayah Kota Pekanbaru merupakan salah satu daerah yang termasuk ke dalam daerah rawan banjir bahkan dikatakan Kota Pekanbaru termasuk kedalam zona merah terkait banjir melihat dari mayoritas daerah yang ada adalah daerah rawah dan pinggiran sungai. Badan Nasional Penanggulangan 
Banjir (BNPB) mencatat, Kota Pekanbaru adalah salah satu Kota yang rawan banjir di pulau sumatra.

Menurut data yang diperoleh dari BPBD Kota Pekanbaru dalam peta rawan banjir wilayah secara keseluruhan, ada satu desa di pinggir Sungai Siak yang tersebar. dipetakan sebagai daerah rawan banjir, sedangkan kecamatan yang lainnya rawan banjir sedang (BNPB, 2011)

Berdasarkan hasil wawancara sementara yang dilakukan oleh penulis kepada pihak BPBD mengenai kejadian banjir alam, pihak BPBD belum memiliki sistem informasi pemetaan secara rial time untuk memantau wilayah bencan. Data banjir sebelumnya dikelola masih secara semi manual yaitu menggunakan Microsoft excel. Untuk menangani masalah ini, perlu dibangun sebuah Sistem Informasi Geografis yang dapat menentukan daerah yang sering terjadi banjir alam.

Sistem informasi geografis diharapkan dapat membantu Dinas BPBD dalam mengelola data banjir yang pernah terjadi berada di Kota Pekanbaru, serta membantu memberikan informasi tentang banjir yang dibutuhkan oleh masyarakat untuk mengantisipasi kejadian banjir selanjutnya.

Selain mementukan daerah rawan banjir bagi Dinas BPBD daerah Kota Pekanbaru, masyarakat juga ingin mengetahui lokasi yang sering banjir dan menentukan kapasitas lama intensitas hujan yang akan mengakibatkan banjir, sehingga tidak menghambat perjalanan beraktifitas seharihari.

Berdasarkan penjelasan diatas, maka penulisa Untuk itu penulis tertarik meneliti dengan judul "Sistem Informasi Geografis Wilayah Rawan Banjir Di Kota Pekanbaru"

\section{Sistem Informasi}

Menurut Tata Sutabri (2012), Sistem informasi dapat di definisikan sebagai berikut : (1) Suatu sistem yang dibuat oleh manusia yang terdiri dari komponen - komponen dalam organisasi untuk mencapai suatu tujuan yaitu menyajikan informasi. (2)Sekumpulan prosedur organisasi yang pada saat dilaksanakan akan memberikan informasi bagi pengambil keputusan dan atau untuk mengendalikan organisasi. (3)Suatu sistem didalam suatu organisasi yang mempertemukan kebutuhan pengolahan transaksi, mendukung operasi, bersifat menajerial, dan kegiatan strategi dari suatu organisasi dan menyediakan pihak luar tertentu dengan laporan yang diperlukan.

\section{Manfaat Sistem Informasi}

Menurut Tata Sutabri (2012), manfaat dari sistem informasi adalah sebagai berikut : (1) Organisasi menggunakan sistem informasi untuk mengolah transaksi - transaksi, mengurangi biaya, dan menghasilkan pendapatan sebagai salah satu produk atau pelayanan mereka. (2) Bank menggunakan sistem informasi untuk mengolah cek - cek nasabah dan membuat berbagai laporan rekening koran dan transaksi yang terjadi. (3) Perusahaan menggunakan sistem informasi untuk mempertahankan persediaan pada tingkat paling rendah agar konsisten dengan jenis barang yang tersedia.

\section{Komponen - komponen Sistem Informasi}

Sistem informasi memiliki komponen - komponen yang akan membentuk sistem informasi tersebut. Kita dapat mengilustrasikan komponen - komponen seperti gambar 1 (Yakub, 2012). 


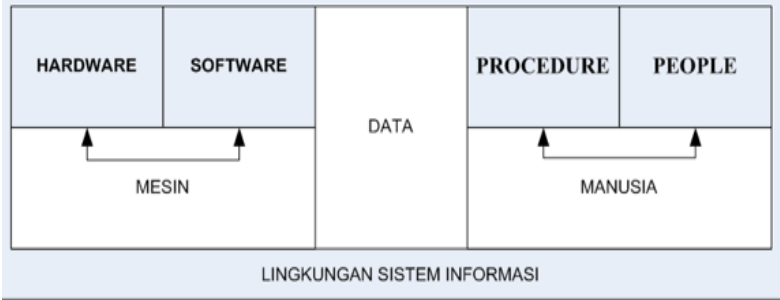

Gambar 1. Lima Komponen Sistem Informasi

Kelima komponen Sistem Informasi pada gambar 1 dapat diklasifikasikan sebagai berikut : (1) Hardware dan Software yang berfungsi sebagai mesin.(2)People dan Procedure yang merupakan manusia dan tatacara menggunakan mesin. (3) Data merupakan jembatan penghubung antara manusia dan mesin agar terjadi suatu proses pengolahan data.

\section{Informasi}

Dalam

menganalisa

dan merencanakan perancangan suatu sistem harus mengerti terlebih dahulu komponen komponen yang ada dalam sistem tersebut. Darimana data dan informasi tersebut diperoleh dan kemana hasil pengolahan data dan informasi tersebut diarahkan. Menurut Davis (1985) dalam Tata Sutabri (2012), informasi adalah sebagai data yang telah diolah menjadi bentuk yang lebih berarti dan berguna bagi penerimannya untuk mengambil keputusan masa kini maupun masa yang akan datang, serta informasi mempunyai ciri benar atau salah, baru, tambahan, dan korektif. (2) Raymond (1995) dalam Tata Sutabri (2012), mendefinisikan informasi sebagai data yang telah diolah menjadi bentuk yang lebih berarti bagi penerimanya. Alat pengolah informasi dapat meliputi elemen komputer, elemen non komputer atau kombinasinya. (3)Menurut Burch dan Gary dalam Tata Sutabri (2012), agar informasi yang dihasilkan lebih berharga, maka informasi tersebut harus memenuhi beberapa kriteria, yaitu informasi harus akurat, informasi harus relevan, dan informasi harus tepat waktu. (4) Kegunaan informasi adalah untuk mengurangi hal ketidakpastian didalam proses pengambilan keputusan tentang suatu keadaan. Ketidakpastian dapat dikurangi dengan mendapatkan informasi tambahan yang berkualitas. Sebagian besar informasi yang dinikmati tidak hanya oleh satu pihak melainkan untuk beberapa kegunaan. Informasi tidak dapat persis ditaksir keuntungannya dengan suatu nilai usang, tetapi dapat ditaksir dari nilai efektifitas (Jogiyanto, 2013).

\section{Sistem Informasi Geografi}

Sistem Informasi Geografis Geographic Information System (GIS) adalah sistem informasi khusus yang mengelola data yang memiliki informasi spasial untuk membangun, menyimpan, mengelola dan menampilkan informasi berefrensi geografis (Gistut, 1994 dalam Prahasta, 2009:85).

Sistem Informasi Georafis merupakan suatu sistem informasi yang berbasis komputer, dirancang untuk bekerja dengan menggunakan data yang memiliki informasi spasial (bereferensi keruangan). Sistem ini mengcapture, mengecek, mengintegrasikan, memanipulasi, menganalisa, dan menampilkan data yang secara spasial mereferensikan kepada kondisi bumi.

Menurut Gistut (1994) dalam Prahasta (2009:85), SIG adalah sistem yang dapat mendukung pengambilan keputusan spasial dan mampu mengintegrasikan deskripsi-deskripsi lokasi dengan karakteristik-karakteristik fenomena yang ditemukan di lokasi tersebut.

Menurut Burrough (1986) dalam Prahasta (2009:85), mendefinisikan SIG adalah sistem berbasis komputer yang digunakan untuk memasukan, menyimpan, 
mengelola, menganalisis dan mengaktifkan kembali data yang mempunyai referensi keruangan untuk berbagai tujuan yang berkaitan dengan pemetaan dan perencanaan. Dari defenisi-definisi tersebut diatas dapat diambil kesimpulan bahwa SIG terdiri atas beberapa subsistem, yaitu data input, data output, data management, data manipulasi dan analisis (Prahasta, 2009:85).

SIG adalah sistem komputer yang digunakan untuk mengumpulkan, memeriksa, mengintegrasikan, dan menganalisa informasiinformasi yang berhubungan dengan permukaan bumi (Prahasta, 2009:62). Sedangkan menurut ESRI definisi SIG adalah kumpulan yang terorganisir dari perangkat keras komputer, perangkat lunak, data geografi dan personil yang didesain untuk memperoleh peta banjir, menyimpan, memperbaiki, memanipulasi, menganalisis, dan menampilkan semua bentuk informasi yang bereferensi geografi (Prahasta, 2009:62).

Menurut Purwadhi (1994) dalam (Prahasta, 2009:85), SIG merupakan suatu sistem yang mengorganisir perangkat keras (hardware), perangkat lunak (software), dan data, serta dapat mendaya-gunakan sistempenyimpanan, pengolahan, maupun analisis data secara simultan, sehingga dapat diperoleh informasi yang berkaitan dengan aspek keruangan.

\section{Ciri-ciri Sistem Informasi Geografi}

Cirri-ciri dari sistem informasi geografi yang dapat dirangkum dalam beberapa poin, yaitu (Prahasta,2009:65) : (1)

SIG memiliki sub sistem input data yang menampung dan dapat mengolah data spasial dari berbagai sumber. Sub sistem ini juga berisi proses transformasi data spasial berbeda jenisnya, misalnya dari peta kontur menjadi titik ketinggian. (b) SIG pemanggilan data yang memungkinkan data spasial untuk dipanggil, diedit, dan diperbaharui. (c) SIG memiliki subsistem manipulasi dan analisis data yang menyajikan peran data, pengelompokan dan pemisahan, estimasi parameter dan hambatan, serta fungsi permodelan. (d) SIG mempunyai subsistem pelaporan yang menyajikan seluruh atau sebagian dari basis data dalam bentuk tabel, grafis dan peta.

\section{Subsistem SIG}

Subsistem yang dimiliki oleh SIG yaitu data input, data output, data management, data manipulasi dan analisis. Subsistem SIG tersebut dijelaskan dibawah ini ( Prahasta,2009:108) :

a. Data Input, Subsistem ini bertugas untuk mengumpulkan dan mempersiapkan data spasial dan data atribut dari berbagai sumber. Subsistem ini pula yang bertanggung jawab dalam mengkonversi atau mentransformasi format data-data aslinya ke dalam format yang digunakan oleh SIG.

b. Data Output, Subsistem ini menampilkan atau menghasilkan keluaran seluruh atau sebagian basis data baik dalam bentuk softcopy maupun bentuk hard copy, seperti tabel, grafik, peta dan lain-lain.

c. Data Management, Subsistem ini mengorganisasikan baik data spasial maupun atribut ke dalam sebuah basis data sedemikian rupa sehingga mudah dipanggil, dan diedit.

d. Data manipulasi dan analisis, Subsistem ini menentukan informasi-informasi yang dapat dihasilkan oleh SIG. Selain itu, subsistem ini juga melakukan manipulasi dan permodelan data untuk menghasilkan informasi yang diharapkan. 


\section{Komponen SIG}

Komponen sistem informasi geografis terdiri dari empat komponen,yaitu (Prahasta, 2009:86):

a. Perangkat keras (Hardware), Pada saat ini SIG tersedia untuk berbagai platform perangkat keras mulai dari PC desktop, workstations, hingga multi user host yang dapat digunakan oleh banyak orang secara bersamaan dalam jaringan komputer yang luas, berkemampuan tinggi, memiliki ruang penyimpanan (harddisk) yang besar, dan mempunyai kapasitas memori (RAM) yang besar.

b. Perangkat lunak (Software), Bila dipandangdari sisi lain, SIG juga merupakan sistem perangkat lunak yang tersusun secara modular dimana basisdata memegang peranan kunci. Setiap subsistem diimplementasikan dengan menggunakan perangkat lunak yang terdiri dari beberapa modul, hingga tidak mengherankan jika ada perangkat SIG yang terdiri dari ratusan modul program yang masing-masing dapat dieksekusi sendiri.

c. Data dan Informasi Geografi, SIG dapat mengumpulkan dan menyimpan data dan informasi yang diperlukan baik secara tidak langsung dengan cara mengimportnya dari perangkat-perangkat lunak SIG yang lain maupun secara langsung dengan cara mendigitasi data spasialnya dari peta dan memasukkan data atributnya dari table-tabel dan laporan dengan menggunakan keyboard.

d. Manajemen, Suatu proyek SIG akan berhasil jika dimanage dengan baik dan dikerjakan oleh orang-orang memiliki keahlian yang tepat pada semua tingkatan. didefinisikan sebagai bahan keterangan tentang kejadian-kejadian nyata atau faktafakta yang dirumuskan dalam sekelompok lambang tertentu yang tidak acak, yang menunjukkan jumlah, tindakan, atau hal. Data dapat berupa catatan dalam kertas, buku, atau tersimpan sebagai file dalam basis data. Data menjadi bahan dalam proses pengolahan data. Oleh karena itu, suatu data belum dapat berbicara banyak sebelum diolah lebih lanjut. Contoh data adalah catatan identitas pegawai, catatan transaksi pembelian, catatan transaksi penjualan, dan lain-lain.

\section{Sejarah Web}

Sejarah situs web bermula di European Laboratory For Particle Physics (lebih dikenal dengan nama CERN). Penelitian ini terletak di kota Geneva dekat perbatasan Prancis dan Swiss. CERN adalah Organisasi Eropa untuk riset nuklir. Seorang fisikawan yang bernama Tim Berners Lee menulis proposal untuk menejemen informasi yang menunjukkan bagaimana informasi dapat dipindahkan dengan mudah melalui internet dengan menggunakan hypertext.

Perkembangan situs web tidak berhenti, selanjutnya seorang insinyur sistem yang bernama Robert Cailliau bergabung dengan idenya yaitu menghubungkan hypertext dengan internet dan komputer pribadi, sehingga mempunyai jaringan tunggal untuk membantu fisikawan CERN berbagi informasi yang tersimpan di laboratorium. Hypertext akan memungkinkan pengguna untuk browsing dengan mudah antara text pada halaman situs web dengan menggunakan link. Contoh pertama yang dikembangkan pada NEXT computer.

\section{Banjir}

Menurut Sutanta (2009), data dapat Banjir adalah peristiwa yang terjadi ketika 
aliran air yang berlebihan merendam daratan. Banjir merupakan fenomena alam yang biasa terjadi di suatu kawasan yang banyak dialiri oleh aliran sungai. Secara sederhana banjir dapat didefinisikan sebagainya hadirnya air di suatu kawasan luas sehingga menutupi permukaan bumi kawasan tersebut (Rahayu, 2009).

Dalam cakupan pembicaraan yang luas, kita bisa melihat banjir sebagai suatu bagian dari siklus hidrologi, yaitu pada bagian air di permukaan Bumi yang bergerak ke laut. Dalam siklus hidrologi kita dapat melihat bahwa volume air yang mengalir di permukaan Bumi dominan ditentukan oleh tingkat curah hujan, dan tingkat peresapan air ke dalam tanah.

Aliran Permukaan $=$ Curah Hujan (Resapan ke dalam tanah + Penguapan ke udara)

Air hujan sampai di permukaan Bumi dan mengalir di permukaan Bumi, bergerak menuju ke laut dengan membentuk alur alur sungai. Alur-alur sungai ini di mulai di daerah yang tertinggi di suatu kawasan, bisa daerah pegunungan, gunung atau perbukitan, dan berakhir di tepi pantai ketika aliran air masuk ke laut. Secara sederhana, segmen aliran sungai itu dapat kita bedakan menjadi daerah hulu, tengah dan hilir.

\section{Jenis-jenis Banjir}

Menurut Rahayu (2009), terdapat berbagai macam banjir yang disebabkan oleh beberapa hal, diantaranya : (1) Banjir air, Banjir yang satu ini adalah banjir yang sudah umum. Penyebab banjir ini adalah meluapnya air sungai, danau, atau selokan sehingga air akan meluber lalu menggenangi daratan. Umumnya banjir seperti ini disebabkan oleh hujan yang turun terusmenerus sehingga sungai atau danau tidak mampu lagi menampung air. (2) Banjir "Cileunang", Jenis banjir yang satu ini hampir sama dengan banjir air. Namun banjir cileunang ini disebakan oleh hujan yang sangat deras dengan debit air yang sangatbanyak. Banjir akhirnya terjadi karena air-air hujan yang melimpah ini tidak bisa segera mengalir melalui saluran atau selokan di sekitar rumah warga. Jika banjir air dapat terjadi dalam waktu yang cukup lama, maka banjir cileunang adalah banjir dadakan (langsung terjadi saat hujan tiba). (3) Banjir bandang, Tidak hanya banjir dengan materi air, tetapi banjir yang satu ini juga mengangkut material air berupa lumpur. Banjir seperti ini jelas lebih berbahaya daripada banjir air karena seseorang tidak akan mampu berenang ditengah-tengah banjir seperti ini untuk menyelamatkan diri. Banjir bandang mampu menghanyutkan apapun, karena itu daya rusaknya sangat tinggi. Banjir ini biasa terjadi di area dekat pegunungan, dimana tanah pegunungan seolah longsor karena air hujan lalu ikut terbawa air ke daratan yang lebih rendah. Biasanya banjir bandang ini akan menghanyutkan sejumlah pohon-pohon hutan atau batu-batu berukuran besar. Materialmaterial ini tentu dapat merusak pemukiman warga yang berada di wilayah sekitar pegunungan. (4)Banjir rob (laut pasang), Banjir rob adalah banjir yang disebabkan oleh pasangnya air laut. Banjir seperti ini kerap melanda kota Muara Baru di Jakarta. Air laut yang pasang ini umumnya akan menahan air sungan yang sudah menumpuk, akhirnya mampu menjebol tanggul dan menggenangi daratan. (5) Banjir lahar dingin, Salah satu dari macam-macam banjir adalah banjir lahar dingin. Banjir jenis ini biasanya hanya terjadi ketika erupsi gunung berapi. Erupsi ini kemudian mengeluarkan lahar dingin dari puncak gunung dan mengalir ke daratan yang ada di bawahnya. Lahar dingin ini mengakibatkan pendangkalan sungai, sehingga air sungai 
akan mudah meluap dan dapat meluber ke pemukiman warga. (6) Banjir lumpur, Banjir lumpur ini identik dengan peristiwa banjir Lapindo di daerah Sidoarjo. Banjir ini mirip banjir bandang, tetapi lebih disebabkan oleh keluarnya lumpur dari dalam bumi dan menggenangi daratan. Lumpur yang keluar dari dalam bumi bukan merupakan lumpur biasa, tetapi juga mengandung bahan dan gas kimia tertentu yang berba haya. Sampai saat ini, peristiwa banjir lumpur panas di Sidoarjo belum dapat diatasi dengan baik, malah semakin banyak titik-titik semburan baru di sekitar titik semburan lumpur utama.

\section{Kategori Banjir}

$\quad$ Kategori atau jenis banjir terbagi
berdasarkan lokasi sumber aliran
permukaannya dan berdasarkan mekanisme
terjadinya banjir:

1. Berdasarkan lokasi sumber aliran permukaannya, terdiri dari :

a. Banjir kiriman (banjir bandang) yaitu banjir yang diakibatkan oleh tingginya curah hujan didaerah hulu sungai.

b. Banjir lokal yaitu banjir yang terjadi karena volume hujan setempat yang melebihi kapasitas pembuangan disuatu wilayah.

2. Berdasarkan mekanisme terjadinya banjir yaitu :
a. Regular flood, yaitu banjir yang diakibatkan oleh hujan.
b. Irregular flood, yaitu banjir yang diakibatkan oleh selain hujan, seperti tsunami, gelombang pasang, dan hancurnya bendungan.

\section{Hujan}

Hujan adalah sebuah presipitasi berwujud cairan, berbeda dengan presipitasi non-cair seperti salju, batu es dan slit. Jenis- jenis hujan berdasarkan besarnya curah hujan menurut BMKG dibagi manjadi tiga, yaitu :

1. Hujan sedang, $20-50 \mathrm{~mm}$ per hari.

2. Hujan lebat, 50-100 $\mathrm{mm}$ per hari.

3. Hujan sangat lebat, di atas $100 \mathrm{~mm}$ per hari.

Intensitas curah hujan merupakan ukuran jumlah hujan per satuan waktu tertentu selama hujan berlangsung. Hujan umumnya dibedakan menjadi 5 tingkatan sesuai intensitasnya seperti yang disajikan pada Tabel 1 berikut ini.

Tabel 1. Tingkatan Hujan Berdasarkan Intensitasnya

\begin{tabular}{cc}
\hline Tingkatan & $\begin{array}{c}\text { Intensitas } \\
(\mathrm{mm} / \mathrm{menit})\end{array}$ \\
\hline $\begin{array}{c}\text { Sangat } \\
\text { lemah }\end{array}$ & $<0.02$ \\
\hline Lemah & $0.02-0.05$ \\
\hline Sedang & $0.05-0.25$ \\
\hline Deras & $0.25-1$ \\
\hline $\begin{array}{l}\text { Sangat } \\
\text { Deras }\end{array}$ \\
\hline
\end{tabular}

Sumber: Mori et al (1997)

\section{Kota Pekanbaru}

Kota Pekanbaru adalah ibu kota dan kota terbesar di Provinsi Riau, Indonesia. Kota ini merupakan kota perdagangan dan jasa, termasuk sebagai kota dengan tingkat pertumbuhan, migrasi dan urbanisasi yang tinggi. Secara geografis kota Pekanbaru memiliki posisi yang strategis berada pada jalur lintas Sumatera, terhubung dengan beberapa kota seperti Medan, Padang, dan Jambi dengan wilayah administratif diapit oleh Kabupaten Siak pada bagian utara dan timur sementara bagian barat dan selatan diapit oleh Kabupaten Kampar. Kota Pekanbaru dibelah oleh sungai Siak yang mengalir dari Barat ke Timur dan berada pada ketinggian berkisar antara 5-50 meter di atas permukaan laut. Kota ini termasuk beriklim tropis dengan suhu udara 
maksimum antara 34-360C dan suhu minimum antara 20-230C .

Sebelum tahun 1960, Pekanbaru hanyalah kota dengan luas $16 \mathrm{~km} 2$ yang kemudian bertambah menjadi 62,96 km2 dengan dua Kecamatan yaitu Kecamatan Senapelan dan Kecamatan Limapuluh. Selanjutnya pada tahun 1965 kota Pekanbaru menjadi enam kecamatan, dan tahun 1987 menjadi delapan kecamatan dengan wilayah wilayah 446,50 km2, setelah pemerintah daerah Kampar menyetujui untuk menyerahkan sebagian dari wilayahnya untuk keperluan perluasan wilayah Kota Pekanbaru, yang kemudian ditetapkan melalui Peraturan Pemerintah Republik Indonesia No. 19 Tahun 1987, dan kemudian pada tahun 2003 jumlah kecamatan pada kota ini dimekarkan menjadi dua belas kecamatan. Sejak Tahun 2010 Pekanbaru telah menjadi kota ketiga berpenduduk terbanyak di Pulau Sumatera setelah Medan dan Palembang. Pekanbaru ditetapkan menjadi Ibu kota Propinsi Riau melalui Keputusan Menteri Dalam Negeri No. 52/I/44-25 tanggal 20 Januari 1959 (Marwan, 2012).

Laju pertumbuhan ekonomi Kota Pekanbaru cukup pesat dan menjadi pendorong bagi laju pertumbuhan penduduknya. Etnis Minangkabau merupakan masyarakat terbesar yang tinggal di Kota Pekanbaru dengan jumlah sekitar $37,96 \%$ dari total penduduk kota. Etnis Minangkabau pada umumnya bekerja sebagai pegawai dan pedagang. Jumlah mereka yang cukup besar telah mengantarkan bahasa Minang sebagai salah satu bahasa pergaulan yang digunakan oleh penduduk Kota Pekanbaru, selain bahasa Melayu dan bahasa Indonesia. Selain itu etnis yang memiliki proporsi yang cukup besar di Kota Pekanbaru adalah Melayu, Jawa, Batak dan Tionghoa. Perpindahan ibu Kota Provinsi Riau dari Tanjung Pinang ke Pekanbaru pada tahun 1959, memiliki andil besar menempatkan suhu Melayu mendominasi struktur birokrasi pemerintahan kota, namun sejak tahun 2002 hegemoni mereka berkurang seiring dengan berdirinya Provinsi Kepulauan Riau dari pemekaran Provinsi Riau

Berikut ini adalah daftar nama-nama Kelurahan atau Desa dan Kecamatan Kota Pekanbaru, Provinsi Riau, yaitu :

\section{Kecamatan Bukit Raya}
a. Kelurahan/Desa Tangkerang Labuai
b. Kelurahan/Desa Dirgantara
c. Kelurahan/Desa Simpang Tiga
d. Kelurahan/Desa Tebingtinggi
e. Kelurahan/Desa Tangkerang Selatan
f. Kelurahan/Desa Tangkerang Utara

\section{Kecamatan Lima Puluh}
a. Kelurahan/Desa Rintis
b. Kelurahan/Desa Sekip
c. Kelurahan/Desa Tanjung Rhu
d. Kelurahan/Desa Pesisir

\section{Kecamatan Marpoyan Damai}
a. Kelurahan/Desa Maharatu
b. Kelurahan/Desa Sidomulyo Timur
c. Kelurahan/Desa Wonorejo
d. Kelurahan/Desa Tangkerang Barat
e. Kelurahan/Desa Tangkerang Tengah

\section{Kecamatan Payung Sekaki}
a. Kelurahan/Desa Air Hitam
b. Kelurahan/Desa Labuh Baru Barat
c. Kelurahan/Desa Labuh Baru Timur
d. Kelurahan/Desa Tampan

\section{Kecamatan Pekanbaru Kota}
a. Kelurahan/Desa Suka Ramai
b. Kelurahan/Desa Suma Hilang
c. Kelurahan/Desa Kota Tinggi
d. Kelurahan/Desa Kota Baru
e. Kelurahan/Desa Tanah Datar
f. Kelurahan/Desa Simpang Empat
6. Kecamatan Rumbai
a. Kelurahan/Desa Sri Meranti
b. Kelurahan/Desa Palas
c. Kelurahan/Desa Rumbai Bukit 
d. Kelurahan/Desa Umban Sari

e. Kelurahan/Desa Muara Fajar

\section{Kecamatan Rumbai Pesisir}

a. Kelurahan/Desa Limbungan

b. Kelurahan/Desa Limbungan Baru

c. Kelurahan/Desa Lembah Sari

d. Kelurahan/Desa Lembah Damai

e. Kelurahan/Desa Meranti Pandak

f. Kelurahan/Desa Tebing Tinggi Okura

8. Kecamatan Sail

a. Kelurahan/Desa Cinta Raja

b. Kelurahan/Desa Suka Maju

c. Kelurahan/Desa Suka Mulia (Sukamulya)

\section{Kecamatan Senapelan}

a. Kelurahan/Desa Sago

b. Kelurahan/Desa Kampung Dalam

c. Kelurahan/Desa Kampung Bandar

d. Kelurahan/Desa Kampung Baru

e. Kelurahan/Desa Padang Terubuk

f. Kelurahan/Desa Padang Bulan

10. Kecamatan Sukajadi

a. Kelurahan/Desa Sukajadi

b. Kelurahan/Desa Harjosari

c. Kelurahan/Desa Kedungsari

d. Kelurahan/Desa Kampung Melayu

e. Kelurahan/Desa Jadirejo

f. Kelurahan/Desa Pulau Karam

g. Kelurahan/Desa Kampung Tengah

11. Kecamatan Tampan

a. Kelurahan/Desa Delima

b. Kelurahan/Desa Tuah Karya

c. Kelurahan/Desa Simpang Baru

d. Kelurahan/Desa Sidomulyo Barat

\section{Kecamatan Tenayan Raya}

a. Kelurahan/Desa Rejosari

b. Kelurahan/Desa Sail

c. Kelurahan/Desa Kulim

d. Kelurahan/Desa Tangkerang Timur

\section{Penelitian Terdahulu}

Sebelum melaksanakan penelitian penulis melakukan studi penelitian yang sudaha ada sebelumnya atau yang sejenis, berdasarkan analisa dan ketentuan yang ada penelitian sebelumnya " Muahammad Sholahuddin pada tahun 2015 dengan judul SIG Untuk Memetakan Daerah Banjir Dengan Metode Skoring Dan Pembobotan (Studi Kasus Kabupaten Jepara).

Berdasarkan pembahasan dan penelitian Muhammad Sholahuddin, peneliti ingin mengambil sampel wilayah di Kota Pekanbaru dan menggunakan metode SIG dengan memetakan berdasarkan wilayah kecamatan.

\section{METODE}

\section{Kerangka Kerja Penelitian}

Untuk mempermudah dalam pengerjaan penelitian ini, maka penulis membuatkan kerangka kerja penelitian seperti pada gambar 3.1 berikut ini.

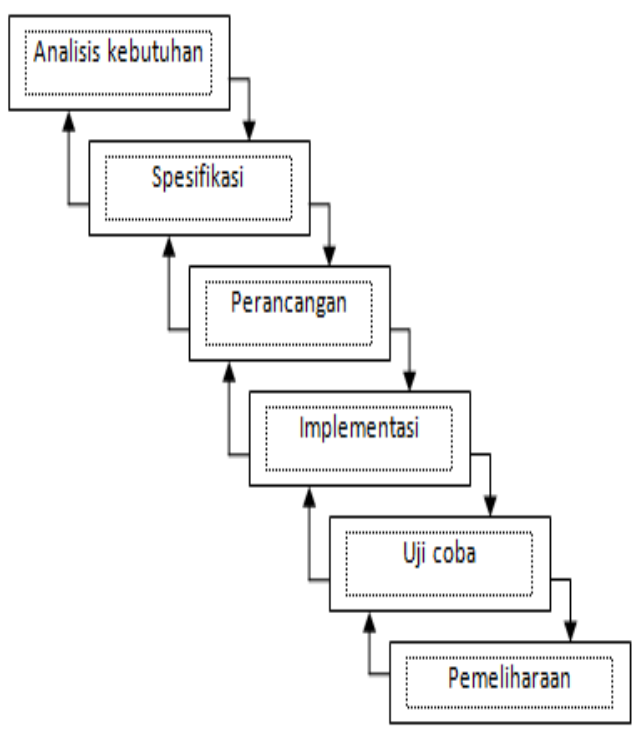

\section{Gambar 3.1 Kerangka Kerja Penelitian}

Gambar 3.1 merupakan kerangka kerja yang digunakan dalam langkah langkah penelitian. Metode penelitian yang digunakan pada penelitian ini adalah metode historis, dimana metode historis bertujuan merekonstruksi masa lalu secara sistematis dan objektif dengan mengumpulkan, menilai, memverifikasi, dan menyintesiskan bukti untuk menetapkan fakta dan mencapai 
kongklusi yang dapat dipertahankan. dan objektif dengan mengumpulkan, menilai, memverifikasi, dan menyintesiskan bukti untuk menetapkan fakta dan mencapai kongklusi yang dapat dipertahankan.

\section{Analisis Kebutuhan}

Tahap analisa kebutuhan merupakan tahap awal pada suatu penelitian tahap ini dilakukan dengan melihat latar belakang dari penelitian, kemudian melihat batasan masalah dan selanjutnya melakukan perancangan sistem informasi geografis agar dapat digunakan dan dapat memberikan manfaat dengan website yang akan dibuat.

\section{Spesifikasi}

Pengumpulan data merupakan langkah kedua dalam melakukan penelitian. Data dikumpulkan dari berbagai sumber yang ada. Pengumpulan data pada penelitian ini dilakukan dengan 3 metode yaitu metode wawancara, studi pustaka (literature), dan laboratorium (laboratory research).

\section{Wawancara}

Metode yang paling banyak digunakan yang melibatkan pembicaraan dengan informasi secara langsung dalam suatu wawancara. Wawancara ialah proses komunikasi atau interaksi untuk mengumpulkan informasi dengan cara tanya jawab antara peneliti dengan informan atau subjek penelitian (Emzir, 2010: 50). Wawancara yang dilakukan penulis pada penelitian ini adalah, melaukan wawancara tentang sistem informasi geografis parawisata di Kota Pekanbaru. Dengan mengumpulkan data lewat informasi yang diberikan informasi kepada penulis, maka penulis akan mengumpulkan data hasil wawancara, kemudian merancang sistem informasi geografis parawisata di Kota Pekanbaru.

\section{Penelitian kepustakaan (library research)}

Melakukan Penelitian di perpustakaan dengan cara mencari buku dan mempelajari literatur yang ada hubungannya dengan masalah yang diteliti. Hal ini sangat berguna untuk pedoman dan referensi bagi penulis.

\section{Perancangan}

Tahap penulisan proses data, aliran proses dan hubungan antar data yang paling optimal dan memenuhi kebutuhan pihak yang sesuai dengan hasil analisa kebutuhan.

1. Perancangan Proses, Rancangan proses menggunakan Diagram Alir Data (DAD) pada sistem informasi geografis pariwisata di Kota Pekanbaru.

2. Perancangan Flowchart, Bagan alir program (flowchart) adalah suatu bagan yang menggambarkan arus logika dari data yang akan diproses dalam suatu program dari awal sampai akhir.

3. Perancangan Basis Data, Desain data adalah aktifitas penting yang dilakukan dalam rekayasa perangkat lunak. Pengaruh struktur program dan kompleksitas prosedural menyebabkan perancangan data berpengaruh penting terhadap kualitas perangkat lunak.

\section{Rancangan Entity-Relationship}

Diagram (ERD), ERD merupakan kumpulan konseptual untuk menggambarkan data, hubungan data, semantik (makna) dan batasannya. ERD disajikan dalam bentuk diagram hubungan entitas yang terdiri dari entitas, atribut, garis penghubung dan relasi.

5. Relasi Antar Tabel, Pemodelan data dalam merancang suatu database adalah dengan menggunakan model relasi antar tabel. Relasi antar tabel terdiri dari komponen-komponen: tabel, field, hubungan atau relasi dan jenis hubungan atau relasi. 
6. Perancangan Tabel, Desain basisdata Rancan bangun sistem informasi geografis parawisata di Kota Pekanbaru

7. Perancangan Antar Muka, Rancangan antarmuka ini terbagi dalam 2 kelompok yaitu rancangan antar muka untuk user sebagai pengguna umum dan rancangan antar muka untuk admin sebagai pengelola data.

a. Perancangan antar muka User

b. Perancangan antar muka admin

\section{Implementasi}

Pada tahap ini penulis mengimplementasikan sistem berdasarkan rancangan yang telah dibuat sebelumnya sesuai dengan kebutuhan pihak terkait.

\section{Uji Coba}

Tahap uji coba merupakan terhadap sistem yang telah dibuat dalam bentuk implementasi dan sekaligus mengevaluasi kekurangan serta kelebihan sistem tersebut.

\section{Pemeliharaan}

Tahap ini dilakukan guna mengevaluasi sistem yang telah dibuat guna memperoleh hasil yang optimal, dan perawatan terhadap sistem bertujuan agar sistem yang sudah terpasang dapat berjalan semakin efektif dan efisien, perawatan sistem baru harus dilakukan secara berturut turut dan terencana. Apabila program terdapat error, maka akan diadakan perbaikan pada program dengan cara memperbaiki dan menghilangkan eror yang terjadi sampai program dapat digunakan dengan baik dan sempurna.

\section{Alat dan Bahan Penelitian}

Spesifikasi hardware pada Laptop/ PC yang digunakan dalam penelitian ini yaitu:

1. Personal Computer (PC) atau Laptop
Personal komputer atau laptop yang digunakan untuk perancangan perangkat lunak dan merupakan sebagai alat testing untuk sistem informasi geografis wilayah rawan banjir di Kota Pekanbaru, dengan spesifikasi sebagai berikut : (a) Merk Perangkat : Personal Computer (PC) atau Laptop (b) Prosessor: Dual CPU @2430M CPU \# 240 Ghz (c)Memori: 4 GB (d)DirectX Version : DirectX 11 (e)VGA: Intel (R) G41 Expres Chipset (f)Type System: 32bit Operating System.

Software-software yang digunakan dalam pembuatan program sistem informasi geografis ini antara lain : (1) Bahasa pemrograman : PHP, (2) MySQL untuk membuat Basis data (database),(3)XAMPP sebagai web server, (4) Web Browser Mozilla Firefox 15.0.1, Chrome, Opera, (5) Microsoft Visio 2007 untuk membuat Rancangan Program

\section{HASIL}

\section{Perancangan Proses}

Rancangan proses menggunakan Data Flow Diagram (DFD), yaitu :

1. Diagram Konteks

Diagram konteks memberikan gambaran seluruh elemen sistem. Terdapat dua entitas luar yaitu :

a. User, sebagai pengguna sistem dan dapat melihat info peta rawan bencana. Pada user terdapat beberapa aliran data, yaitu data kecamatan dan data buku tamu.

b. Admin sebagai pengolah sistem, pada admin terdapat aliran data yaitu, data login, data kecamatan dan data keterangan idensitas cuaca.

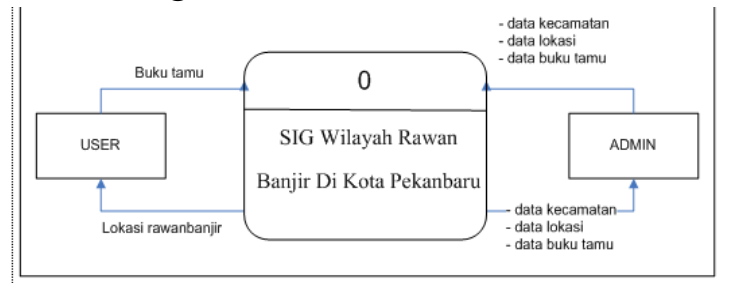

Gambar 2. Diagram Konteks 


\section{DFD Level 1}

Pada proses Sistem Informasi Geografis Wilayah Rawan Banjir Di Kota Pekanbaru ini, terdiri dari 2 proses untuk user yaitu, buku tamu dan peta wilayah rawan banjir dan ada 5 proses untuk admin yaitu, login, olah peta wilayah banjir, olah kecamatan, dan ubah password. Dapat dilihat pada gambar 3 .

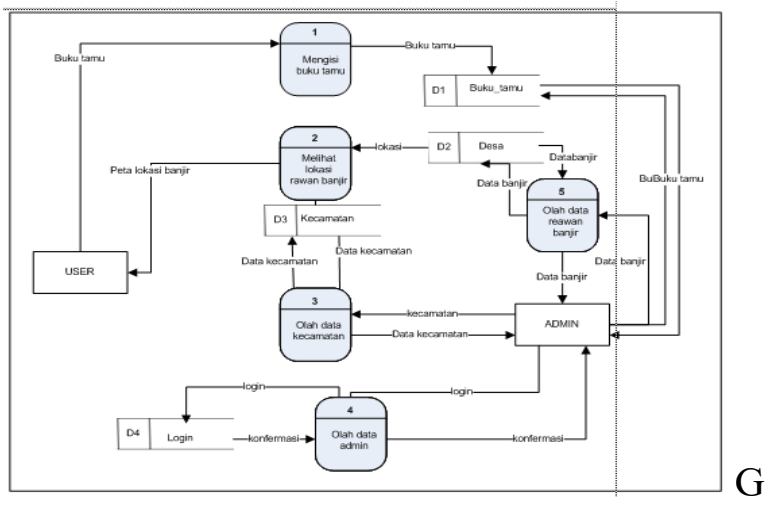

Gambar 3. DFD level 1

3. Entity-Relationship Diagram (ERD)

ERD disajikan dalam bentuk diagram hubungan entitas. Terdiri dari entitas, atribut, garis penghubung dan relasi. ERD merupakan kumpulan konseptual untuk menggambarkan data, hubungan data, semantik (makna) dan batasannya. Tampilan dari ERD dapat dilihat pada gambar 4.

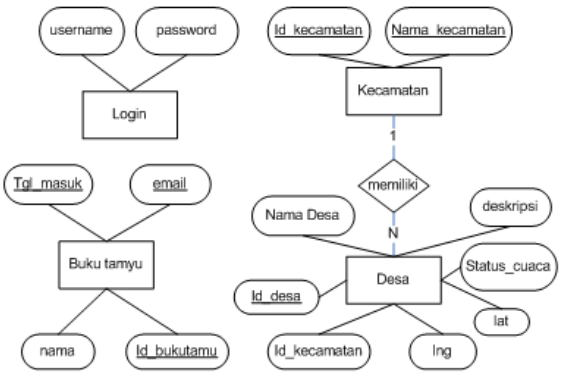

Gambar 4.

Rancangan Entity-Relationship Diagram

(ERD)

Gambar 4.3 merupakan salah satu bentuk relasi antar entitas dari masingmasing entitas, dimana terdiri dari entitas, atribut dan relasi nya. Atribut dari masingmasing entitas adalah :

a. Admin terdiri dari : username, dan password.

b. Buku tamu terdiri dari : id_bukutamu,nama, email, pesan dan tanggal masuk.

c. Lokasi terdiri dari : id lokasi, id kecamatan, alamat, nama lokasi, latitude dan longitude.

d. Kecamatan terdiri dari : id_kecamatan dan nama_kecamatan.

4. Perancangan Tabel

Desain basisdata perancangan Sistem Informasi Geografis Wilayah Rawan Banjir Di Kota Pekanbaru terdiri dari lima tabel. Berikut ini adalah penjelasan dari tabel yang dibutuhkan :

1. Tabel Login admin

Tabel login terdiri dari 2 field yaitu username dan password.

2. Tabel Buku Tamu

Tabel buku tamu merupakan tabel basis data yang digunakan untuk menyimpan data buku tamu, yang telah diisi oleh user yang berisi komentar tentang isi dari web tersebut.

3. Tabel Lokasi

Tabel Desa merupakan tabel yang digunakan untuk menyimpan data Desa kecamatan yang bertujuan untuk mengolah data Desa yang ada pada halaman Desa.

4. Tabel Kecamatan

Tabel kecamcatan merupakan tabel yang digunakan untuk menyimpan data kecamatan yang bertujuan untuk mengolah data kecamatan yang ada pada halaman kecamatan.

\section{Perancangan Antar Muka}

Perancangan antar muka merupakan bentuk desain sebuah program yang dibuat, dibagi menjadi dua yaitu, perancangan user 
dan admin.

\section{a. Perancangan User}

Halaman user adalah halaman yang muncul pertama kali ketika user masuk pada sistem. Tampilan halaman utama dapat dilihat pada gambar 5 .

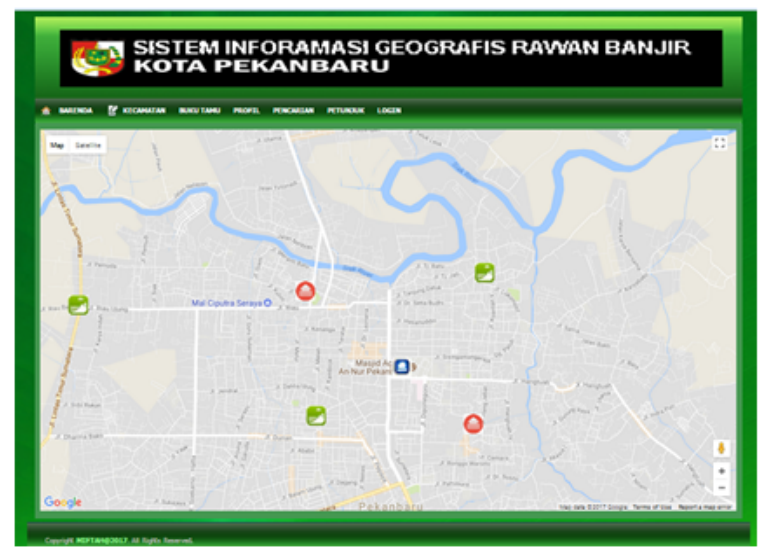

Gambar 5. Tampilan Halaman User

Pada gambar 5 merupakan cara melihat kondisi setiap kecamatan di Kota Pekanbaru, kondisi tersebut tergantung berdasarkan warnanya, warna merah kondisi banjir besar, kondisi hijau normal, dan kondisi biru banjir. Letak masing-masing titik adalah melalui koordinat latittud dan longitude.

b. Perancangan Admin

Halaman adamin berfungsi untuk mengelola data yang akan dijadikan sebagai informasi lokasi yang rawan banjir di wilaya Kota Pekanbaru. Tampilan dari halaman data dapat dilihat pada gambar 6 .

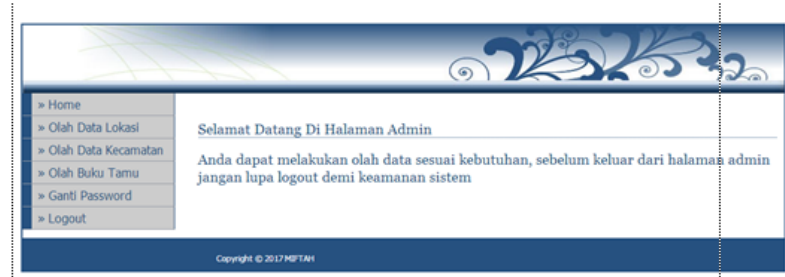

Gambar 6. Tampilan Halaman Admin

\section{KESIMPULAN}

Dari penelitian yang telah dibuat, maka didapatlah sebuah kesimpulan, bahwa
1. Dengan bantuan suatu sistem untuk menentukan lokasi rawan banjir di Kota Pekanbaru, maka dapat memudahkan dalam perjalanan dan memprediksi cuaca setiap kecamatan di Koata Pekanbaru.

2. Sistem yang sudah di buat dapat di fungsikan sebagai informasi luas wilayah dan titik lokasi yang rawan banjir, kemudian alternatif yang wilayah sekitar nya untuk dijadikan rute perjalanan.

3. Sistem dibuat langsung melalui google map dan harus terkoneksi dengan jaringan internet.

\section{DAFTAR PUSTAKA}

[1]. BNPB, 2011, PeraturanKepala Badan Nasional Penanggulangan Bencana, Setandarisasi Peraturan Nasional PNPM

[2]. Chosmin S. Widodo dan Jasmadi. Panduan Menyusun Bahan Ajar Berbasis Kompetensi. Jakarta: Elex media Komputindo, 2008

[3]. Diar Puji. 2010. Menjadi Programmer Jempolan Menggunakan PHP. Yogyakarta: Penerbit MediaKom.

[4]. Jogiyanto,2005.Metodologi Penelitian Sistem Informasi. CV Andi Offset. Yogyakarta

[5]. Jogiyanto,2013.“Teori Portofolio dan Analisis Investasi”, BPFE Yogyakarta, Edisi Kedelapan, Yogyakarta

[6]. Kristanto.2008. Perancangan Sistem Informasi dan Aplikasinya Gava Media, Yogyakarta.

[7]. Nugroho,2008. Analisa dan Perancangan Sistem Informasi dengan metologi Berorientasi Objek, Penerbit Informatika, Bandung

[8]. Peranginangin, Kasiman. 2006. Aplikasi WEB dengan PHP dan MySQL, Yogyakarta: Andi.

[9]. Prahasta, Eddy.2009. Sistem Informasi Geografis

Konsep-konsepDasar. 
Bandung: Informatika Bandung.

[10]. Rahayu, Harkunti P. 2009. Banjir dan

Upaya penanggulanganya. Bandung:

Promise Indonesia

[11]. Sutanta. 2009. Sistem Informasi

Manajemen. Graha Ilmu. Yogyakarta.

[12]. Tata Sutabri. 2012. Analisis Sistem Informasi. Andi. Yogyakarta

[13]. Yakub. 2012. Pengantar Sistem Informasi, Yogyakarta: Graha Ilmu.

[14]. http://www.pekanbaru.go.id : akses 27 Maret 2017 